\title{
PRÁTICA EDUCATIVA: \\ ENTRE O ESSENCIALISMO E A PRÁXIS
}

\author{
Hilda Maria Martins Bandeira* \\ Ivana Maria Lopes de Melo Ibiapina**
}

\section{RESUMO}

A prática educativa é utilizada com frequência na literatura como equivalente à pedagógica, à docente e à práxis. Este artigo pretende analisar a prática educativa a partir de sua interação com a educação da Grécia Clássica e a influência iluminista e romântica de Rousseau, bem como sua contribuição para compreensão na tripla dimensão da prática educativa. Parte da premissa de que a prática educativa é multidimensional e de que prática pedagógica e prática docente são modalidades daquela. Os resultados deste estudo bibliográfico de tese de doutorado focalizam que a prática educativa se desenvolve e se atualiza conforme as necessidades do contexto sócio-histórico, e que a práxis entendida como relação intrínseca entre teoria e prática constitui a possibilidade emergente da prática transformadora.

Palavras-chaves: Prática educativa. Prática pedagógica. Prática docente. Práxis.

\begin{abstract}
EDUCATIONAL PRACTICE: BETWEEN ESSENTIALISM AND PRAXIS

Educational practice is often used in literature as equivalent to pedagogical practice, teaching practice and praxis. This article aims to analyze the educational practice from its interaction with the education of Classical Greece and the enlightenment and romantic influence of Rousseau as well as its contribution to understanding the triple dimension of educational practice. It starts from the premise that educational practice is multidimensional and that pedagogical practice and teaching practice are modalities from the first one. The results of this bibliographical study of doctoral thesis show that educational practice is developed and updated as required for the socio-historical context, and that praxis understood as an intrinsic relationship between theory and practice is the emerging possibility of transformational practice.
\end{abstract}

Keywords: Educational practice. Pedagogical practice. Teaching practice. Praxis.

\footnotetext{
* Doutora em Educação pela Universidade Federal do Piauí (UFPI). Professora Adjunta DE. Endereço para correspondência: UFPI, Campus Ministro Petrônio Portella, Centro de Ciências da Educação/DMTE. CEP: 64049-550 - Teresina, PI. hildabandeira@, ufpi.edu.br ou hildabandeira@hotmail.com

${ }^{* *}$ Doutora em Educação pela Universidade Federal do Rio Grande do Norte (UFRN). Professora Associada DE. Endereço para correspondência: UFPI, Campus Ministro Petrônio Portella, Programa de Pós-Graduação em Educação (PPGEd). CEP: 64049550 - Teresina, PI. ivanaibiapina@ufpi.edu.br
} 


\section{Tecendo o diálogo}

A expressão prática educativa é utilizada com frequência na literatura como equivalente a prática pedagógica, a prática docente e a práxis (SOUZA; BATISTA NETO; SANTIAGO, 2009; ZABALA, 1998), notadamente, quando se relaciona à atividade desenvolvida no âmbito escolar. É primordial examinarmos seus fundamentos. É possível perguntar: esses conceitos de prática educativa não estariam sendo utilizados de forma restrita? O que é educação? Qual seria a natureza da prática educativa e em que ela se distingue ou se aproxima daquelas formas de práticas? Como Vázquez (2007), ao desenvolver a categoria filosófica práxis, e Freire (2005) constroem o movimento de superação do essencialismo e do naturalismo pedagógico?

Considerando o exposto, estruturamos o artigo em três momentos. No primeiro, contextualizamos a temática a partir do diálogo com a Grécia Clássica, situando a problemática a partir do ideal de educação da Paideia (JAEGER, 2010); e rever do "Emílio, ou da Educação" (ROUSSEAU, 2004), a natureza da prática educativa. No segundo momento, o foco está na prática educativa, evidenciando os atributos pedagógico e docente. E no terceiro momento, as possibilidades da articulação com a práxis (VÁZQUEZ, 2007).

Compreender o que é a prática educativa implica entender que tipo de atividade é a educação. No mundo ocidental, a referência é a Grécia Clássica. Desde a sua origem, a educação foi uma tarefa coletiva. Inicialmente, quando ainda não existiam escolas como as de hoje, a educação era ministrada pela própria família, em consonância com a tradição religiosa. Com o advento da polis ${ }^{1}$, surgiram as primeiras escolas. A educação é pensada desde a Antiguidade, a prática de educar constitui o princípio pelo qual os grupos humanos conservam e asseguram suas peculiaridades físicas e espirituais.

Se desde a sua gênese a educação era uma tarefa compartilhada coletivamente, nas sociedades primitivas cabia aos adultos apresentar às crianças e aos jovens as normas e os valores do grupo. Em decorrência, dado o grau de desenvolvimento

1 Modo de vida urbano, base da civilização ocidental. Entre os séculos V e VI começa a formação da polis. da sociedade, que naturalmente é compelida a necessitar de educação, emerge a escola como atividade setorizada, conferida a especialistas. $\mathrm{O}$ ato de educar, que antes era difuso e exercido por todos, torna-se privilégio de algumas pessoas, que são os professores, e, de modo geral, realizado em lugares específicos, as escolas. O termo educação, comumente referido ao ato educativo, designa a prática educativa social, situada num determinado tempo e espaço. A educação é decorrente das relações entre os seres humanos, e, uma vez que o desenvolvimento social é tributário da consciência das produções que orientam a vida humana, a história da prática educativa está condicionada pela transformação dessas relações e produções consideradas adequadas a cada sociedade.

$\mathrm{O}$ retorno às fontes reside na necessidade existencial do ser humano em conhecer a herança cultural e a influência que ela exerce sobre o meio e as pessoas. Da Grécia Clássica, apreenderam-se as formas de pensamento, a oratória, a filosofia, dentre outros aspectos. O povo grego não criou códigos, leis para serem aplicadas, mas buscou a lei a partir das próprias coisas para orientar a vida e o pensamento. "Os Gregos viram pela primeira vez que a educação tem de ser um processo de construção consciente" (JAEGER, 2010, p. 13). A formação do homem grego pressupunha a formação nas dimensões corpo e espírito. Os gregos perspectivaram que o ato de educar é uma ação complexa.

A prática educativa desenvolvida pelos gregos tinha como eixo central a formação do homem em seus vários aspectos. Era uma educação essencialmente antropológica, considerava o homem dotado de razão e que carecia de saber autônomo, sistemático e rigoroso. Nesse contexto, nasceu o pensamento adotado pela educação ocidental, como episteme, e não mais como práxis. A propósito, essa "práxis em grego antigo significa a ação de levar algo a cabo, mas uma ação que tem um fim em si mesma [...]" (VÁZQUEZ, 2007, p. 28).

Educação e formação não são provenientes do acaso, mas decorrentes de um trabalho consciente, e procederam do tipo de aristocracia cavalheiresca na Grécia. A princípio, educação e formação eram limitadas à reduzida classe social, a nobreza. Quando a sociedade burguesa dominante adotou-as como formas, aqueles ideais converteram- 
-se em bem universal e em norma para todos, consolidando-se, pois, como prática educativa.

Cada sociedade prepara o indivíduo para participação nas várias instâncias da vida. Toda sociedade tem sua prática educativa, ambas se exigem e se interpenetram. A educação desenvolvida na Grécia possibilitou a produção de prática educativa. Prática essa manifestada nas ações, nas atitudes, nas aptidões e nos conhecimentos, ou seja, gestada e limitada à nobreza. Nesse cenário, destacava-se a influência dos sofistas e de Sócrates com o poder da retórica, do discurso, a fim de bem educar o cidadão.

Os sofistas representavam pensadores ambulantes que se apresentavam como professores e ensinavam de forma remunerada. Para eles, não interessava que a ideia defendida fosse errada, o que interessava era convencer o outro pela oratória. Os pressupostos de Sócrates, ainda que não intencionassem educar o homem, contrapunham-se à educação perspectivada pelos sofistas, pois o eixo era a preocupação com a ação do homem no mundo a partir de seus próprios conhecimentos, com base na reflexão dialógica. Nesse entorno, destacavam-se dois tipos de educadores: o sofista, que ensinava com base na intuição e no adestramento, através de forma estandardizada de educar; e o socrático, para quem o saber era o alimento do espírito, submetido à análise, a fim de averiguar se esse seria adequado.

$\mathrm{Na}$ Grécia Clássica, o projeto educativo era reservado à formação aristocrática, ou seja, destinado à educação de alguns cidadãos da polis. Os gregos não educavam para a profissão ou negócio. Os sofistas educavam os homens de Estado e dirigentes para atuarem na vida pública. Com eles, a educação era qualificada como arte ou técnica. Sócrates, por meio da interrogação maiêutica ${ }^{2}$, tentava combater os sofistas.

Com os filósofos das luzes, do século XVIII, a educação tornou-se, pelo menos em princípio, um direito de todos. O filósofo e pedagogo Rousseau, influenciado pelas luzes da razão, disseminou os fundamentos sobre os quais é edificado o sistema de ensino da cultura ocidental. Para ele, educar era, sobretudo, distanciar o homem dos costumes

\footnotetext{
2 "Maiêutica", em grego, quer dizer "parto das ideias". Consiste em fazer perguntas e analisar as respostas sucessivas até chegar à verdade do enunciado (CHAUÍ, 2003, p. 123).
}

da aristocracia da época, orientada em torno das convenções sociais. No projeto educativo de Rousseau, traçado para educar seu aluno fictício, Emílio, a educação era a expressão livre do indivíduo no contato com a natureza, cujo objetivo refere-se a "formar um homem livre, capaz de se defender contra todos os constrangimentos." (ROUSSEAU, 2004, p. XXI). Para o filósofo, o único modo de formar esse homem era considerá-lo como ser livre desde a sua infância.

Rousseau (2004), mesmo influenciado pelo cenário da modernidade, desconfiava que as luzes da razão viessem a se acender em cada indivíduo e, em decorrência, viabilizar um homem melhor. Ele acreditava no poder da educação: "tudo o que não temos ao nascer e de que precisamos quando grandes nos é dado pela educação" (ROUSSEAU, 2004, p. IX). A educação começou com o existir da vida e no contato com a natureza, com os homens e com as coisas. $\mathrm{O}$ desenvolvimento das capacidades do homem era a educação pela natureza; o modo como ensinado a usufruir desse desenvolvimento é a educação dos homens; e a aquisição da própria experiência sobre os objetos que afetam o homem era a educação pelas coisas.

Se a prática educativa é parte integrante da educação e da sociedade, aquela que foi desenvolvida na Grécia, e a educação natural, proposta por Rousseau, além de exigência da vida social, também constituem forma de prover as pessoas dos conhecimentos e das experiências culturais conforme o meio social e em razão de suas necessidades, num determinado tempo e lugar. Tanto na Paideia quanto no Emílio de Rousseau fica evidente que a condição humana é a vocação comum do indivíduo.

Os gregos descreveram a educação como a virtude $^{3}$ humana mais difícil de adquirir, e que sua essência emerge quando se abandona a ideia de adestramento. Os gregos dedicaram-se com afinco ao seu projeto de educação do homem. No entendimento de Jaeger (2010, p. 14), “A [...] descoberta do Homem não é a do eu subjetivo, mas a consciência gradual das leis gerais que determina a essência humana. O princípio espiritual dos gregos não é o individualismo, mas o humanismo [...]". Para os gregos, a palavra educar contém configuração ar-

3 Virtude para os gregos se aproximava da palavra areté. É uma disposição para a prática do bem. 
tística e plástica, cuja essência consiste em moldar a pessoa pela norma da comunidade.

Por meio dessa imagem do homem real, conforme as leis da comunidade, os gregos, paulatinamente, adquiriram consciência clara do significado do problema da educação. A inter-relação entre educação natural e educação moral perpassa todo o projeto educativo de Rousseau, com o seguinte fundamento: "Homens, sede humanos, este é vosso primeiro dever; sede humanos para todas as condições, para todas as idades, para tudo o que não é alheio ao homem" (ROUSSEAU, 2004, p. 72).

$\mathrm{Na}$ prática educativa desenvolvida na Grécia, a razão estava acima dos mitos e o homem era o ser mais importante, os instrumentos estavam a seu serviço. Essa prática apresentava duas finalidades: desenvolvimento do cidadão fiel ao Estado; e a formação do homem equilibrado com domínio de si. Um menino ateniense começava sua vida escolar aos seis anos e ficava sob os cuidados do pedagogo, que ensinava Aritmética, Literatura, Música, Escrita, Educação Física, além de vigiar seu comportamento moral. A ação educativa não se limitava à escola, o teatro também era a escola de todos os cidadãos. Meninas não recebiam qualquer educação formal, aprendiam os ofícios domésticos e os trabalhos manuais com as mães.

$\mathrm{Na}$ Grécia Clássica, a vida em sociedade, regulada por leis e pela maneira correta de agir em comunidade, possibilitou um modo de fazer educação que perpassou a modernidade, cujo eixo era a dimensão antropológica. Em Rousseau, essa prática fundamentava-se em um projeto que foi fruto de mais de 20 anos de meditação e três anos de escrita, cujo foco era a dimensão antropológico-filosófica, visando ao desenvolvimento sensitivo, cognitivo e moral do homem em um meio de possibilidades abstratas de relações com o mundo real. Na pedagogia naturalista de Rousseau, o homem, com sua individualidade, representava o eixo central, o homem diante de si mesmo e de seu preceptor. E o mundo e as relações sociais diante desse homem? Como integrar a proposta de Rousseau ao ensino de um grupo de alunos em face da realidade do mundo da modernidade?

Os valores veiculados por Rousseau são individualismo, liberdade e bondade. A educação, para ele, constituía o meio para o homem sair da história e retomar ao seu estado natural, ou seja, criar um indivíduo livre dos males da sociedade. Essa corrupção do homem, segundo Rousseau, aconteceu em decorrência do homem ter se afastado demais do seu estado de natureza. Na verdade, Rousseau (2004) não faz referência à forma de ensino coletivo, embora isso já fosse realidade naquele contexto da modernidade. A influência do seu pensamento teve poucos efeitos sobre as práticas educativas dos dois séculos posteriores (XVIII e XIX). O filósofo e pedagogo Pestalozzi (1746-1821) pôs em prática as ideias de Rousseau (ARANHA, 2006). Salvaguardando essa experiência, as ideias de Rousseau reapareceram no Século XX, com o movimento da Pedagogia Nova.

Não é possível falar de um começo da educação, pois na verdade ela principia com a própria humanidade e se atualiza para cada contexto social, histórico, político e cultural em um determinado tempo e lugar. Toda sociedade educa, haja vista transmitir às gerações costumes, hábitos, maneiras de fazer e de conhecer. Por outro lado, o ensino não nasceu colado à humanidade, começou com os gregos, quando questionaram a natureza, a sociedade, os hábitos, a maneira de governar e de educar. Foi nesse contexto que sofistas, Sócrates e Platão, propuseram uma maneira de educar. Os sofistas ${ }^{4}$ são considerados os primeiros professores.

Se a educação existe em toda parte, o que dizer da natureza da prática educativa? A intenção de expressá-la pressupõe tomar a educação como objeto da prática já vivenciada, produzida. Por exemplo, na Grécia, o modelo vivido representa a essência, tanto a reflexão quanto a prática dos homens estão a serviço dessa essência, e a educação sustenta a cultura e impede a manifestação da ideologia. Embora ainda não se possa falar de projeto pedagógico, haja vista não existisse pedagogia no sentido estrito entre os gregos, é possível expressar que eles desenvolveram reflexão sobre os fundamentos da educação e, como consequência, a prática educativa conforme as necessidades daquele contexto.

4 Para Sócrates, Platão e Aristóteles, os sofistas são sujeitos que usam argumentos capciosos em favor do falso, dando-lhe aparência de verdadeiro. 
Da educação desenvolvida na Grécia, a humanidade herdou a reflexão dos grandes princípios básicos centrados no racionalismo e no humanismo. Não se trata ainda da instrução de crianças na sala de aula, pois humanismo, racionalismo e espírito crítico são ideais educativos e privilégios de uma minoria de homens adultos. A partir da contribuição de Rousseau, instala-se um discurso que não situa mais o adulto, mas a criança no centro da educação. Um dos principais legados deixados pelos gregos às gerações futuras foi a prática educativa desenvolvida com adultos já formados e que precisavam do discurso para se transformar. As crianças ${ }^{5}$, notadamente na Grécia Antiga, eram educadas na família, pois, de fato, os gregos não conheceram a instituição escola, concebida como espaço coletivo sob a orientação de professores que ensinam determinado programa.

Passados mais de 200 anos, a âncora lançada por Rousseau (2004) para se perceber a criança nela mesma, ainda que no plano teórico, expressa um programa educativo e chama atenção para a importância das regras práticas de orientação dos educadores para o trabalho com os alunos. Embora ocorram diferenças substanciais entre os pressupostos da educação grega e de Rousseau, é possível encontrar elementos comuns, como, por exemplo, o fato de que a prática educativa desenvolvida em ambas as modalidades privilegia a dimensão antropológica, a condição existencial das necessidades naturais, físicas e imediatas em face de sua realidade. Com o processo de democratização da sociedade, a educação é dirigida para todas as classes, ou seja, o professor ensina para a coletividade e num espaço específico, conserva os referenciais humanistas de influência da Grécia (JAEGER, 2010) e da educação naturalística de Rousseau (2004). A educação tem alcançado projeções para além das nossas necessidades imediatas, o que justifica, em parte, a celeuma em torno da busca de uma denominação de prática que coadune com as necessidades e com o contexto social emergente. Depois de trilhar na contextualização da prática educativa, segue a discussão referente à sua tripla faceta.

5 Exclusivamente para uma minoria de meninos adolescentes, pois a educação grega não atingiu a infância.

\section{Prática educativa: a tridimensionalidade}

A educação existe em diferentes espaços e tempos, nas mais variadas formas, faz parte do conjunto de necessidades humanas e é condição precípua do processo de humanização. O desenvolvimento da sociedade, entre outros aspectos, trouxe a exigência de mais educação, por conseguinte, influencia na maneira que cada grupo social constrói sua prática educativa. O sentido e o significado da prática educativa não permanecem indiferentes a essas crises sociais, culturais e ideológicas. Se a compreensão do processo de ensino passa pela consideração do conjunto das atividades educativas exigidas pela sociedade, logo não se pode pensar a prática educativa restrita ao espaço da sala de aula. Como é corroborada na Paideia (JAEGER, 2010, p. 4), a educação não é propriedade de um indivíduo, "mas pertence por essência à comunidade". Essa, pois, tem grande influência no esforço de educar seus membros de acordo com o sentir de cada nova geração.

A prática educativa é ação social intencional, é parte integrante da vida, do crescimento da sociedade. Todos nós desenvolvemos prática educativa, independentemente do contexto, da concepção filosófica e pedagógica. Tanto na Paideia quanto em Rousseau, encontramos alusão apenas à prática educativa. Como essas práticas se distinguem?

O trabalho de Souza, Batista Neto e Santiago (2009) anuncia esses conflitos e defende a hipótese de que a formação de professores envolve um coletivo de instituições, de sujeitos e de práticas. O sentido da prática educativa, tal como a definição de sociedade, tem mudado e tem relação com a concepção educacional e com as necessidades produzidas em cada contexto sócio-histórico. Para a discussão neste trabalho, defende-se o pressuposto de que a prática educativa é multidimensional, e de que a prática pedagógica e a prática docente são modalidades daquela. Se é possível falar em prática educativa em qualquer sociedade, logo, ela sempre existiu, ainda que de modo assistemático. Outro aspecto, que é preciso esclarecer, é que, em sentido lato, a prática é genérica, existe em grande variedade. Em sentido estrito, é possível vinculá-la a uma instituição específica com finalidades explícitas de 
instrução e de ensino por meio de ação consciente, deliberada e planejada. Ainda assim, não se separa daquela forma de prática geral. São diversas as modalidades que assumem a prática educativa, sejam intencionais ou não intencionais, formais ou não formais, escolares ou extraescolares, mas todas se interpenetram, a atividade educativa é sempre situada e tributária do modelo de sociedade que lhe faz exigência e determina suas finalidades. Nessa conjuntura, a que prática educativa nós nos referimos ao abordarmos prática pedagógica e prática docente?

Essa indagação remete a duas alternativas: a sociedade que se tem; e a consequente educação veiculada. A educação é atividade desenvolvida há milhares de anos, e isso implica que a prática educativa também é milenar, enquanto a escola é secular. Mesmo que a gênese da educação seja anterior à escola, a associação entre ambas naturalizou-se de tal forma que comumente é remetida para o espaço escolar. Nesses termos, o desenvolvimento das condições de vida humana, as mudanças do cenário social e do trabalho também influenciaram a atividade educativa. Na medida em que o indivíduo se relaciona com o outro e com o meio ambiente, ele é compelido a ter necessidades. Essas necessidades estão associadas ao conjunto das relações sociais.

Heller (1986), ao analisar a teoria das necessidades em Marx, ressalta que ela tem raiz histórico-filosófico-antropológica. No processo de produção da sociedade, essas necessidades se desenvolvem e se modificam, e isso delineia nova forma de organizar a prática educativa. Nesse âmbito, na Grécia e em Rousseau não se fazia referência à prática pedagógica e à prática docente, talvez porque não constituíssem a necessidade fundamental. A atividade educativa tem caráter pedagógico, por isso convém tecer algumas considerações para esclarecimento do triângulo prática educativa, prática docente e prática pedagógica.

A educação ainda conserva o ideal educativo da Paideia, que é contribuir para o processo de humanização ${ }^{6}$ das pessoas, em seus diversos aspectos. Seus objetivos vêm adquirindo diferentes carac-

6 Para os gregos, a humanização não está diretamente relacionada à subjetividade, mas especialmente à consciencialização das leis gerais que determinam a essência humana. Nas palavras de Jaeger (2010, p. 14-15): "Humanismo vem de humanitas". terísticas, tais como: educação escolar, educação paralela, religiosa, profissional, entre outras. Também tem ocorrido esse movimento com a prática educativa, que na tentativa de esclarecer, há quem crie mais atributos, muitas vezes não garantindo diferença substancial. Por exemplo, Souza, Batista Neto e Santiago (2009, p. 35 e 69) substituem por práxis: “[...] entendemos a prática pedagógica como uma práxis. [...] prática educativa analisada reflexivamente, teorizada e realizada pelo coletivo institucional é o que denomino de práxis pedagógica." Em decorrência, prática educativa, prática pedagógica e prática docente estão interconectadas e confinadas por meio de objetivos específicos de educação.

Os pensadores gregos lançaram as sementes da reflexão para fundamentar a educação, enquanto a reflexão sobre os problemas relacionados à escola, à instrução e à prática educativa apareceram mais tarde na História. Não restam dúvidas que tanto Jaeger (2010) quanto Rousseau $(2004,2010)$ influenciaram sobremaneira a educação atual, mas a sociedade é dinâmica e prenhe de necessidades que se remetem há um tempo e a um lugar.

Quando Rousseau prioriza a educação pelas coisas em detrimento da educação pelas palavras, avança em relação à concepção essencialista, pois substitui o conhecimento da essência pelo conhecimento do homem e de suas sensações. No entanto, o eixo fundamental no âmbito da prática educativa não é a negação do logos para ação ou seu contrário, mas a compreensão sinérgica de cada um dos intervenientes na atividade educativa, na sua universalidade e singularidade.

Assim, não é possível negar que a influência do pensamento moderno decorre da cosmovisão ${ }^{7}$ grega, e que na atualidade esses pressupostos têm deixado suas marcas. O esforço de buscar avançar tanto com o essencialismo quanto com o naturalismo idealista pode ser encontrado na proposta pedagógica da práxis dialógica freireana e na argumentação da filosofia da práxis em Vázquez. Nas circunstâncias atuais, a prática educativa que faz sentido não é só a que se firma apenas no ideal de humanização, mas também está impregnada da

\footnotetext{
Conjunto das ideias presentes e vigentes numa determinada sociedade ou implícitas numa teoria sistematizada. Pode-se consultar Severino (2007, p. 53).
} 
práxis designada como prática humana objetiva e subjetiva com intencionalidade reflexiva, ou seja, com um elevado nível de consciência dela.

Em Freire (2005) e Vásquez (2007), o homem não é produto da natureza, mas da História. Dessa maneira, ao longo do desenvolvimento histórico e filosófico no pensamento pedagógico aparece a contraposição teoria e prática. Há momentos em que a teoria apresenta-se tão onipotente em suas relações com a realidade que só se vê a si mesma e configura-se de tal modo que, aparentemente, pode mostrar-se como práxis ${ }^{8}$. Também ocorre com a prática, que às vezes é apreciada como simples aplicação ou degradação da teoria, como, por exemplo, foi o ponto de vista do pensamento grego antigo. Nas duas situações, não se reconhece a unidade indissolúvel entre teoria e prática, ou seja, a práxis.

Considerando o exposto, o trabalho de Franco (2012) discute as práticas pedagógicas a partir da relação com o objeto da Didática. Segundo a autora, prática pedagógica diz respeito às práticas sociais com propósito intencional de realiza-se no pedagógico, e prática docente torna-se pedagógica quando, além de ser prevista a intencionalidade, ocorre que a consciência mantém-se ativada tanto no planejado quanto no realizado.

Não desprezamos a faceta educacional das práticas como processos, tal fundamentação é genérica na sua qualificação. Vamos procurar os fios para tecer a singularidade. Todas as práticas constituem campos que partilham a ação educativa, a intencionalidade, pois a vida social é fundamentalmente prática. Agimos sobre e a partir das suas necessidades (MARX; ENGELS, 2002). Entendemos que três aspectos influenciam a compreensão das práticas, sejam elas educativas, pedagógicas ou docentes: as necessidades, o nível de consciência e o estado de intencionalidade.

Condições sócio-históricas, pressupostos, conceitos e volitividade contribuem na produção das manifestações das práticas referidas. Antecipação dessa prática, baseada no conhecimento e nas ligações necessárias do objeto e sobre a compreensão do que se passa na realidade imediata e mediata, constituem trabalho do pensamento e da ação, con-

8 Característica, sobretudo, do idealismo, especialmente em Hegel. Maiores esclarecimentos em Vázquez (2007, p. 243). correndo para sua compreensão e transformação. Para Cheptulin (2004), a consciência antecipa a realidade inexistente, transforma dada possibilidade da matéria em realidade. Por conseguinte, sem esse plano antecipado, indicando os caminhos da realidade conforme as necessidades, torna-se impossível a transformação, pois "[...] a consciência [é] aspecto necessário da atividade produtiva" (CHEPTULIN, 2004, p. 104). Produção e consciência são desenvolvidas concomitantemente.

Num sentido amplo, prática educativa, como já explicitado, é ação intencional que acontece em diferentes lugares e tempos; prática pedagógica é um processo educativo que também se dá em vários espaços, no atendimento das necessidades sociais práticas e teóricas; prática docente traz o atributo de ser exercida por profissional do ensino, cuja ação, seja ela sistemática ou assistemática, dá-se sempre no ambiente escolar. Souza, Batista Neto e Santiago (2009, p. 24) asseguram: “[...] temos de afinar nossa reflexão para não confundir ou não reduzir a concepção de prática ou práxis pedagógica à prática docente".

É necessário admitir que a prática docente, atribuída à função do professor em contexto escolar, traz a expectativa de que quem a desenvolve volta-se para finalidades e objetivos intencionais reflexivos-críticos. Todavia, considerando que a profissão docente engloba profissionais de diferentes áreas, portando diferentes concepções, dentre outros aspectos, advém a explicação da ausência ou da insuficiência de conhecimentos pedagógicos. Prática docente remete à ação do professor e ao contexto escolar, mas isso não é suficiente e necessário para qualificá-la de pedagógica. É pedagógica quando a intencionalidade é ação planejada e concretamente realizada com estado ativo da consciência, tanto no ato idealizado quanto na sua operacionalização.

Então, considerando a tridimensionalidade da prática educativa, compreende-se que os níveis de práxis destacados por Vázquez (2007), incluindo desde ação espontânea, reiterativa, reflexiva, e que, com maior grau de expansão, chega-se à criativa, de fato são esses níveis que qualificam as faces dessas práticas.

Destarte, necessidades advêm da prática, são manifestadas no trabalho, na criação ou na práxis, 
têm finalidades, cuja realização exige trabalho ativo da consciência e das condições materiais. Como a realidade não está determinada na sua completude, a necessidade em desenvolver práxis no contexto das práticas existe em possibilidades, cuja realidade carrega a premissa abstrata do devir. Sendo assim, o docente é parte responsável na construção de sua história, de suas necessidades da vida pessoal e profissional. Nesse processo, compreender a relação teoria e prática é condição fundamental para possibilitar práxis.

Em Freire (2005, 2011), a natureza humana não é portadora de uma especificidade da qual se extrai sua essência, como entendia a pedagogia da essência. O ser humano se constrói historicamente, logo não é possível distanciar o homem do contexto, dos constrangimentos, dos aspectos negativos ou contraditórios. Nesses termos, embora aconteçam circunstâncias de opressão, ainda existe a possibilidade de que o indivíduo se transforme.

O problema de quem ensina e aprende não está limitado ao ato de comunicar o conhecimento e o processo pelo qual se chegou a ele, mas, notadamente, ao problema de permitir vivência produtiva de conhecimento. Entendemos que, nesse processo, os envolvidos tornam-se conscientes de sua educação ou de sua prática educativa, no sentido de que a entendam e a expandam.

A consciência do inacabamento do indivíduo implica em sua educabilidade. $\mathrm{O}$ ato educativo está associado à tomada de consciência da situação real dos que nela interagem. "O estado e as palavras são igualmente expressões da prática dos homens, e conscientizar é assumir a consciência deste fato" (FREIRE, 2011, p. 20). Nesse âmbito, consciência tem caráter teórico-prático, está vinculada à vida social. Por essa via, o autor, indica: "[...] conscientização muitas vezes significa o começo de uma posição de luta." (FREIRE, 2011, p. 15). O agir consciente, nesse ponto, sugere não somente o conhecimento de si mesmo, mas o indispensável reconhecimento da relação com o outro e com o contexto.

Quanto à dimensão da prática educativa, esta tem alcance pedagógico, filosófico, social e histórico, e por isso é apropriado falar de uma consciência da práxis educativa como articulação entre atividade objetiva e subjetiva do homem. Em Vázquez
(2007), o trabalho de educação da consciência está entre a atividade teórica e a prática transformadora, envolvendo a organização dos procedimentos materiais e da planificação da ação. Dessa posição, deduz-se que a unidade teoria-prática dá-se por meio de várias mediações, pois a atividade da consciência é “[...] inseparável de toda verdadeira atividade humana, apresenta-se [...] como elaboração de fins e produção de conhecimentos em íntima unidade" (VÁZQUEZ, 2007, p. 224).

$\mathrm{Na}$ intenção de analisar os posicionamentos teóricos referentes ao conceito de práxis, optamos por discutir aspectos fundamentais destacados especialmente por Vázquez (2007), Marx e Engels (2002) no entendimento da categoria práxis, na relação produzida entre teoria e prática e a dupla função da práxis: práxis criadora perante a práxis reiterativa, práxis reflexiva perante a práxis espontânea, focalizando as possibilidades na docência.

\section{Práxis e possibilidade na docência}

A formulação de problema é condição para qualquer desenvolvimento do conhecimento científico. Contudo, como expressamos a práxis? Esse é o impasse sobre o qual se pretende refletir. Incialmente apresenta-se o problema da linguagem, da consciência da práxis e da linguagem no vocabulário materialista, assim como as condições que tornam possível a transição da teoria à prática, assegurando a unidade entre ambas.

O termo práxis é empregado com sentido equivalente de prática; tanto na língua espanhola, como na portuguesa e na alemã, advém da antiguidade grega, ao designar ação acabada. O emprego indistinto dessa linguagem, que encerra a ação em si ou fora dela, contribuiu para a banalização desse uso dominante na linguagem comum; a práxis, quando é devidamente reconhecida, advém do vocabulário filosófico. Vázquez (2007) reconhece o uso restrito do termo práxis e o elege, assim, pelas seguintes razões: precaver do sentido de prática em seu uso cotidiano utilitário; o significado de práxis não se identifica com o original da língua grega; tem aproximação com "poiésis" (poesia, poeta ou poético), dado o sentido de criação, tem configuração específica que dissimula a práxis no sentido mais amplo. Considerando a insuficiência da origem 
do termo e o sentido pragmático, Vázquez (2007, p. 28) designa práxis: "atividade consciente objetiva", cujo lugar central na filosofia não se limita a interpretar o mundo, mas também como aspecto de transformação.

Essas explicações terminológicas do sentido da práxis são fundamentais no entendimento de sua história, sua estrutura e sua organização. Nesses termos, a Filosofia, como área do conhecimento, interpreta o desenvolvimento da natureza, da sociedade e do pensamento, e expressa as conquistas da ciência e das atividades práticas (AFANASIEV, 1968).

Necessidades da prática social constitui dispositivo para ação e transformação da realidade. Tal premissa surgiu na consciência filosófica moderna, concepção, em geral, alheia ao mundo grego. No pensamento grego, atividades teórica e prática se davam em campos separados: a primeira para os filósofos, e a segunda para os escravos, cujo fim era $o$ atendimento das necessidades humanas. A consciência filosófica da práxis, na fase do Renascimento, sofreu alteração ao realçar o papel da criação, limitada a personalidades iluminadas, ou seja, a teoria continuava com status superior ao da prática. Nesses contextos, o trabalho carecia de estrutura material-social. A compreensão de que se produz e age na realidade material implica em práxis, mas como a consciência comum pode desligar-se dessa concepção ingênua e espontânea para expandir-se a uma consciência reflexiva?

Buscam-se esclarecimentos a esse problema, a partir das teses de Marx e Engels (2002) sobre Feuerbach, por compreender que nelas encontram-se a afirmação da práxis como processo teórico e prático da atividade material produtiva do domínio do homem sobre a natureza e de sua própria condição de a ela transformar e por ela ser transformado. O problema da relação entre o ser cognoscente e o objeto cognoscível aparece no pensamento de Marx (2001), em "Manuscritos Econômicos e Filosóficos", ou seja, antes da elaboração das teses surgem como conteúdo explícito, nos quais as ligações da prática são atadas como fundamento de reciprocidade entre homem e natureza e entre sujeito e objeto. Essas considerações permitem expressar que nos "Manuscritos Econômicos e Filosóficos," o conceito de práxis material predomina o caráter antropológico da influência feurbachiana. O desen- volvimento ulterior do pensamento de Marx em “A Ideologia Alemã” propicia expansão do conceito de práxis, ao considerar a formação da história humana. Essa descontinuidade não é absoluta, só pode ser entendida com grau de implicação de certa continuidade ou unidade (VÁZQUEZ, 2007).

A teoria da práxis, nas 11 teses sobre Feuerbach, supera o sentido da prática como ideia de ação pragmática. A práxis surge nas suas vertentes: ontológica, considera o homem na relação como o meio e outros seres; gnosiológica, conhecimento como critério de verdade; e revolucionária, como meio de transformação das circunstâncias. Essa concepção materialista da História correlacionada à práxis, em suas diferentes vertentes, representa condição necessária para expansão da consciência filosófica da prática educativa em seu sentido pleno de práxis que, além de interpretar, transforma.

O problema das relações entre teoria e prática é desenvolvido ao longo das 11 teses, notadamente nas Teses 1,2, 3 e 11. Na primeira tese, é colocada em suspeição a dialética idealista do século XVIII e princípio do século XIX, em face de a realidade ser contemplativa, do conhecimento ser criado fora da sociedade. A contribuição dessa tese está na prática como fundamento do conhecimento e a rejeição da possibilidade de conhecer a margem da prática. Na segunda tese, é demonstrada a função da prática na compreensão da realidade; à medida que é processo e produto de nossa atividade, a teoria ganha corpo no movimento da realidade, sob a forma de atividade prática. A terceira tese tem como expressão "a práxis revolucionária", que acontece à medida que transformamos as circunstâncias e a nós também (VÁZQUEZ, 2007). Torna-se indispensável saber quem são os educadores e se suas opções são meramente pedagógicas ou se estão no caminho da prática revolucionária, pois a práxis que se constitui unidade entre teoria e prática não se contenta em interpretar, mas, com base nessa, transformar (Tese 11).

O processo do conhecimento baseia-se na prática, na atividade produtiva. Desde o início da história humana, há necessidades de elaboração dos instrumentos para suprir a própria vida. Sob a influência dessas necessidades práticas, a capacidade cognoscitiva se desenvolveu; em decorrência, outras necessidades surgiram. Inclusive é proce- 
dente a assertiva: "o conhecimento é a atividade teórica dos homens" (AFANASIEV, 1968, p. 182), e a teoria só se concretiza na medida em que é a realização das necessidades humanas.

Nesses termos, Vázquez (2007) destaca algumas condições para a práxis verdadeira: a aceitação de uma determinada teoria; análise dessa teoria aceita e de suas implicações na realidade; compreender quem aceitou e analisou a referida teoria. A anuência da teoria é condição principal de uma práxis verdadeira, todavia não é ainda atividade transformadora, dada a exigência da análise do tipo de teoria e de homem. A produção dessa crítica precisa ser radical, compreender o homem em seu contexto concreto e nas suas necessidades e relações mediadas. Em síntese, nas relações entre teoria e práxis a teoria em si não se materializa, sua articulação é condicionada pela existência de uma necessidade radical que se explica como crítica também severa, que torna possível sua aceitação.

\section{Considerações finais}

As práticas e as necessidades não existem em si. Elas são sempre relativas aos indivíduos, aos contextos e decorrem das relações com a História, com a sociedade e com a cultura existente, ou seja, produzir a prática é uma necessidade que é atualizada em cada conjuntura, seja profissional, pessoal ou social, que se teve, tem e que terá. Os significados, inicialmente abrangentes, entram em simbiose com os sentidos produzidos por cada ato pessoal e grupal, resultando, pois, em práticas que se interpenetram, têm unidade, ainda que não se caracterizem em identidade. Por conseguinte, prática educativa, prática pedagógica e prática docente, em determinado momento, se constituíram em práxis.

A práxis é uma totalidade prático-social que pode adquirir diferentes formas e níveis se levar-se em conta a matéria sobre a qual é exercida a prática transformadora. Partindo dessas relações, é possível produzir nova realidade, conforme dois critérios niveladores vazquezianos: grau de penetração da consciência no processo ativo da prática; e grau de criação ou de humanização demonstrado na matéria transformada. Assim, produzir práxis constitui necessidade e possibilidade emergente da prática educativa no cenário atual do contexto sócio-histórico e cultural.

\section{REFERÊNCIAS}

AFANASIEV Victor. Fundamentos de filosofia. Rio de Janeiro: Civilização Brasileira, 1968.

ARANHA, Maria Lúcia de Arruda. Filosofia da educação. 3. ed. São Paulo: Moderna, 2006.

CHAUI, Marilena. Convite à filosofia. 13. ed. São Paulo: Ática, 2003.

CHEPTULIN, Alexandre. A dialética materialista: categorias da dialética. São Paulo: Alfa-Omega, 2004.

FRANCO, Maria Amélia Santoro. Práticas pedagógicas nas múltiplas redes educativas. In: LIBÂNEO, Carlos; ALVES, Nilda. Temas de Pedagogia: diálogos entre didática e currículo. São Paulo: Cortez, 2012. p. 169-188.

FREIRE, Paulo. Pedagogia do oprimido. 49. ed. Rio de Janeiro: Paz e Terra, 2005.

Educação como prática de liberdade. 14. ed. Rio de Janeiro: Paz e Terra, 2011.

HELLER, Agnes. Teoría de las necessidades em Marx. 2. ed. Barcelona: Feltrinelli Editore, 1986.

JAEGER, Werner. Paideia: a formação do homem grego. 5. ed. São Paulo: Martins Fontes, 2010.

MARX, Karl. Manuscritos econômicos e filosóficos. Formação crítica de educadores: questões fundamentais. 3 ed. São Paulo: Martin Claret, 2001.

MARX, Karl; ENGELS, Friedrich. A ideologia alemã: teses sobre Feuerbach. São Paulo: Centauro, 2002.

ROUSSEAU, Jean-Jacques. Emílio ou da educação. 3. ed. São Paulo: Martins Fontes, 2004.

Discurso sobre as ciências e as artes: discurso sobre a origem e os fundamentos da desigualdade entre os homens. São Paulo: Martin Claret, 2010. 
SEVERINO, Antônio Joaquim. Filosofia. 2. ed. São Paulo: Cortez, 2007.

SOUZA, João Francisco de; BATISTA NETO, José; SANTIAGO, Eliete (Org.). Prática pedagógica e formação de professores. Recife: Editora Universitária da UFPE, 2009.

VÁZQUEZ, Adolfo Sánchez. Filosofia da práxis. Buenos Aires: Consejo Latinoamericano de Ciências Sociales - CLACSO; São Paulo: Expressão Popular, 2007.

ZABALA, Antoni. A prática educativa: como ensinar. Porto Alegre: ArtMed, 1998.

Recebido em: 30.05 .2014

Aprovado em: 02.10.2014 